The $B D J$ News section accepts items that include general news, latest research and diary events that interest our

readers. Press releases or articles may be edited, and should include a colour photograph if possible. Please direct your correspondence to the News Editor, Arveen Bajaj at the BDJ, The Macmillan Building, 4 Crinan Street, London N1 9XW or by email to bdj@bda.org

\section{Focus on the first year of reforms}

Reforms to NHS dentistry have failed to increase access to services, according to a recently published government report. NHS dental reforms: one year on showed 28.1 million people had been to an NHS dentist in the previous 24 months. This was 50,000 down on the figures on the eve of the changes in April 2006. The number of dentists in the system had also fallen.

The government claims the changes are allowing the local NHS to develop services in areas with most need, as under the old system, the NHS had no control over how much dentistry was provided locally or where it was provided. Now they say the local NHS is using its new powers to establish dental practices in areas where they did not previously exist.

The reforms were designed to address access to services, the remuneration system, and patient charges. The report acknowledged there was still more to do to help people who were looking to find an NHS dentist.

However the British Dental Association (BDA), commenting on the report said that the reforms had failed to inspire confidence in the dental profession, improve access or encourage a more preventive approach to dental care.

BDA Chief Executive Peter Ward said, 'The report recognises the importance of genuine local flexibility for patient care but this can only be achieved by moving away from the rigidity of this crude target-driven contract. The government must start listening to the profession and patients if local commissioning is to provide the services that local communities deserve.'

\title{
BDA museum receives grant
}

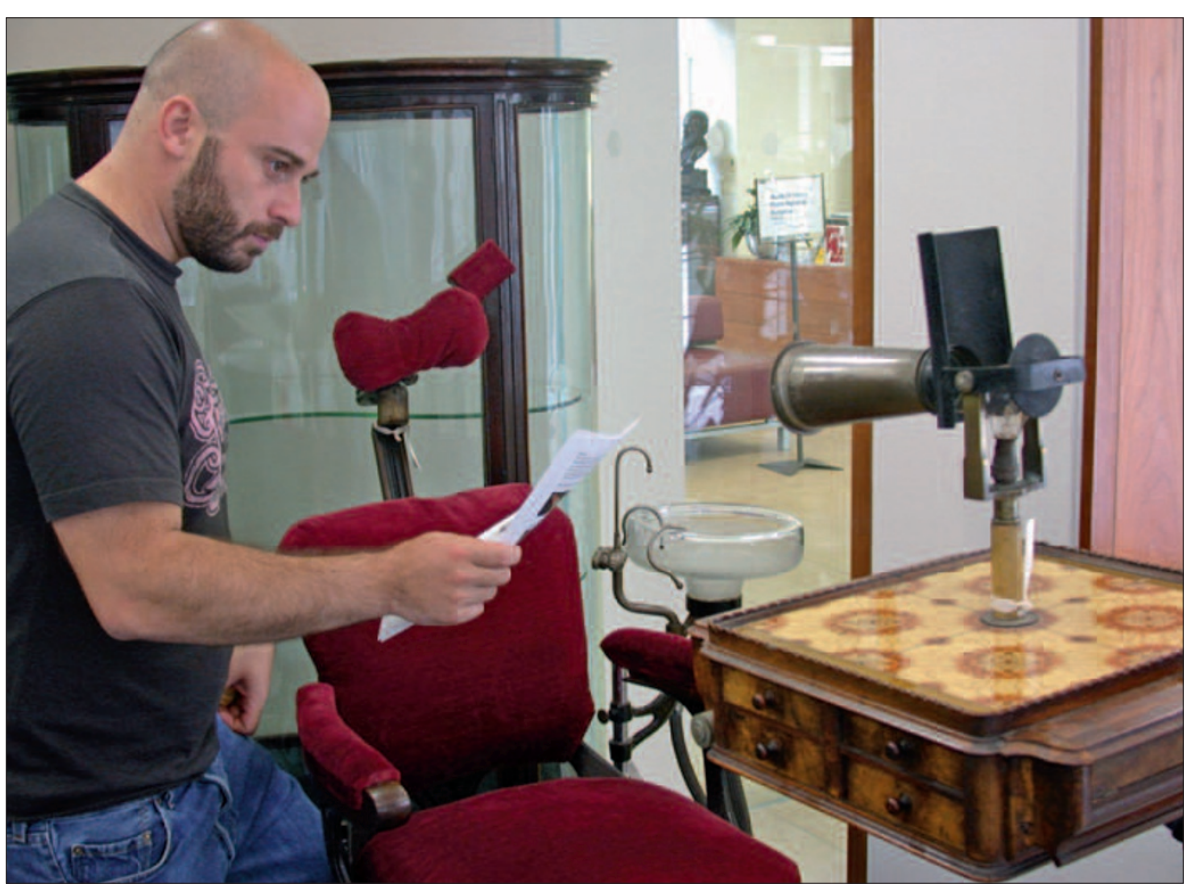

The British Dental Association's museum has been awarded a grant of $£ 1,276$ by the Museums, Libraries \& Archives, London (MLA London), a government body which oversees museums in the capital.

The grant has been given for the museum to work with ESOL (English for Speakers of Other Languages) students at Westminster Kingsway College. The aim of the project is for the participants to develop learning resources relating to the museum and the history of dentistry for their fellow students whose first language is not English. It will also contribute to the healthcare unit of their citizenship curriculum.

Sally Dummer, Acting Head of Museum Services said, 'Dentistry is a subject of universal appeal, which crosses cultural boundaries and is relevant to everyone. We are delighted that this imaginative and inventive project has been given financial support by MLA London. It builds on our previous successful work with new audiences such as schools and community groups and will help us engage with a further new audience.' Pictured above, the BDA Museum will be producing resources with ESOL students to help in their understanding of the displays.

\section{Aesthetic and functional dentistry}

Oral Makeovers was the theme of this year's Welsh Annual Rural Dental Conference. Key members of the dental profession attended the conference in Gregynog, near Newtown, the eighth organised by the Welsh Rural Postgraduate Unit under the auspices of the Institute of Rural Health.
'The conference theme was a response to the changing demand for aesthetic as well as functional dentistry and the importance and desirability of capturing that image in the dental surgery,' explained Charles Vaughan Jones, Post-Graduate Dental Tutor for rural Wales. 


\section{Charity rebrands}

Oral health charity Dentaid is rebranding to reflect its continual growth. It hopes that its new logo will become widely recognised as a symbol of the progress that the charity is making within the under-served oral healthcare sector in the developing world.

As well as a new logo and colour scheme, Dentaid is also launching a new website (www.dentaid.org). This will become a resource centre for people worldwide to learn about oral health care and for overseas projects to be able to download training manuals, advice and video clips free of charge.

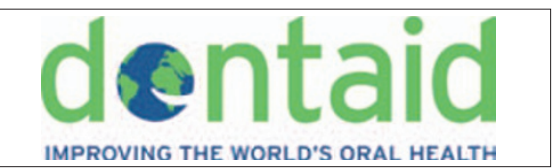

\section{Dental professionals in business}

The GDC is seeking views on its draft guidance for registrants concerning their responsibilities when acting in a business capacity. The guidance, Principles of management responsibility, will apply to any registrant who has a management role, whether that is in a dental body corporate, a primary care trust, a dental practice, a dental laboratory or elsewhere.

Since the opening of the new Dental Care Professionals Register (DCP) in July 2006, GDC-registered dental care professionals have been able to 'carry on the business of dentistry', which means that they are legally able to own their own practices, go into partnerships with each other or dentists, and employ other members of the dental team.

In July 2006 there were also changes to the Dentists Act which removed the limit on the number of dental bodies corporate which can exist. This means that any dental practice or group of practices can now become a corporate body.

The consultation document is available on the GDC website at www.gdcuk.org. The closing date for responses is 14 September 2007.

\section{Collective awarded cash for HIV research} ence and Craniofacial Biology has been awarded a five-year, \$6,258,768 grant from the US National Institute of Dental and Craniofacial Research (NIDCR) to head up research into HIV.

The collective will consist of four interrelated research projects, along with administrative/biostatistical and clinical core components. Dr Daniel Malamud from New York University College of Dentistry (NYUCD, USA) says the collective's overall goal is to define the interactions between host defence molecules and bacteria in HIV infection and subsequent antiretroviral therapy.

The group will be made up of teams from NYUCD, New York University School of Medicine (NYUSoM) and the Aaron Diamond AIDS Research Center (ADARC). Dr Malamud commented, 'We are going to recruit a population of people that are HIV-infected but are drug naïve, so they have not even been put on treatment yet. New York City is probably one of the few places [in the US] where the study could be done.'

The entire proposal utilises the same case-controlled study population consisting of 85 HIV positive, HARRT - highly aggressive anti-retroviral therapy - naïve subjects who will subsequently begin antiretroviral therapy.
A New York Professor of Basic Sci-
There will also be a similar cohort of HIV negative subjects. The clinical core will obtain oral and GI samples, monitor patient progress, carry out complete oral health examinations and maintain all subject records.

Dr Malamud continued, 'We want to see how various parameters throughout the GI tract are affected by HIV infection and then by the subsequent control of HIV through a cocktail of drugs, known as HARRT.

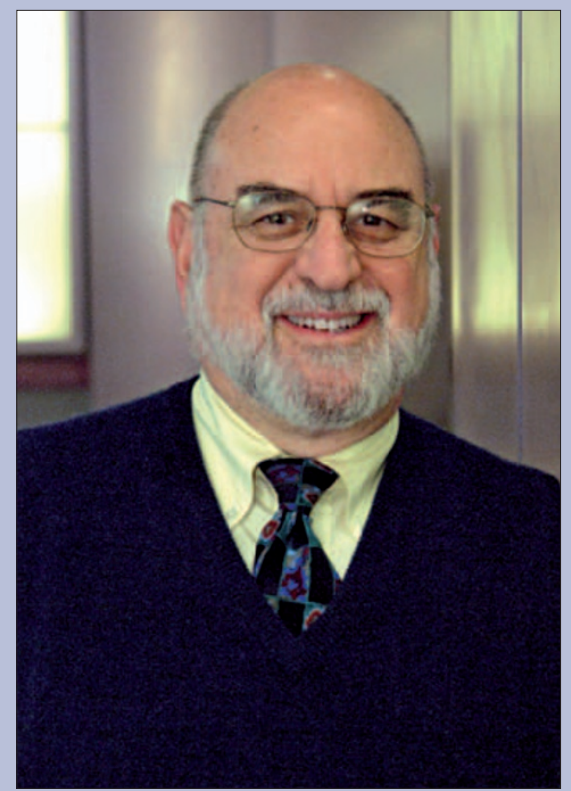

Dr Daniel Malamud

\section{Overseas appointment for London specialist}

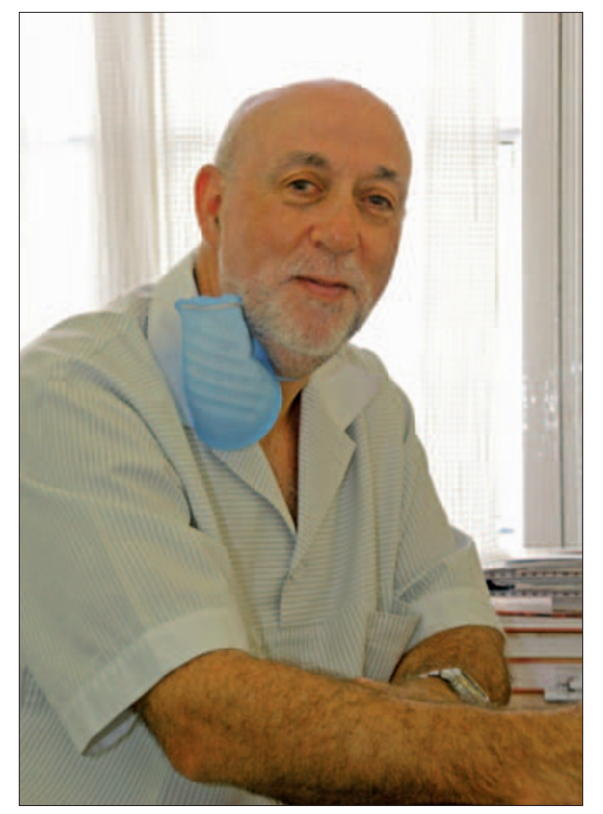

Dr Edwin Scher, a dentist in the field of implants in the UK, has been appointed Visiting Professor at Temple University, Philadelphia USA in the the Department of Periodontology and Oral Implantology.

Dr Scher is a specialist in oral surgery and prosthdontics and has been placing dental implants since 1986. He has been involved in continuing education since 1990 and more recently, surgery guided courses.

He has addressed many international congresses around the world and was recently course moderator at the World Congress in Las Vegas. He is a founder member of the Association of Dental Implantology UK (ADI) and a board member of the Intenational Congress for Oral Implantologists. He also sits on the editorial board of many dental journals. 


\section{Damage caused by brushing may help keep gums healthy says new research}

Researchers have found that one way regular brushing may help keep gums firm and pink is, paradoxically, by tearing open cells. Bristles wielded with even gentle force tear holes in the epithelial cells that line the gums and tongue, causing a momentary rupture, researchers at the Medical College of Georgia (MCG) in Augusta (USA) report.

Tearing enables calcium, abundant in saliva, to move into the cells, triggering internal membranes to move up and patch the hole, says Dr Katsuya Miyake, MCG cell biologist and the paper's cofirst author. However, researchers say that in the seconds that repair takes, growth factors that promote growth of collagen, new cells and blood vessels leak out of injured cells.

Cell injury also turns on expression of the c-fos gene, an early-response gene often activated under stress that may be the first step in a response such as cell division or growth.

Dr Paul L. McNeil, MCG cell biologist and corresponding author explained, 'It is very clear that brushing your teeth is a healthy thing to do but we are thinking that there might be another positive aspect of brushing. Many tissues in our bodies respond to mechanical stress by adapting and getting stronger, like muscles. We think the gums may adapt to this mechanical stress by getting thicker and healthier. It is the no pain, no gain theory, the same as exercising.'

The research team, which also includes Dr Kaori Amano, a dental researcher at Kyorin University of Medicine in Japan, and Dr James L. Borke, MCG physiologist, injected a fluorescent dye into the blood stream that can only get into torn cells. They then brushed the teeth, gums and tongue of rats with a modified electric toothbrush. 'We saw lots of bright cells, and suggest that in addition to its well-known ability to remove bacteria and their harmful products from teeth, brushing may, by causing plasma membrane disruptions, lead to local cell-adaptive responses ultimately of benefit to gingival health.'

One immediate area of interest resulting from the research is to identify chemical signals produced by wounded oral cavity cells that could promote gum health. The method or type of brush might strongly influence the extent of epithelial cell-wounding and subsequent liberation of factors that promote gum health.

Researchers also found that brushing injures not only epithelial cells on the tongue's surface but muscle cells underneath as well. Dr McNeil continues, 'The mechanical forces must have been transmitted through the intact epithe-

lium to the muscle cells which means our epithelium is tough and maintains a nice, resilient barrier but, not surprisingly, since it is not a hard surface, it transmits forces quite readily.'

The article Breaking biological barriers with a toothbrush appears in the Journal of Dental Research (2007; 86: 769-774).

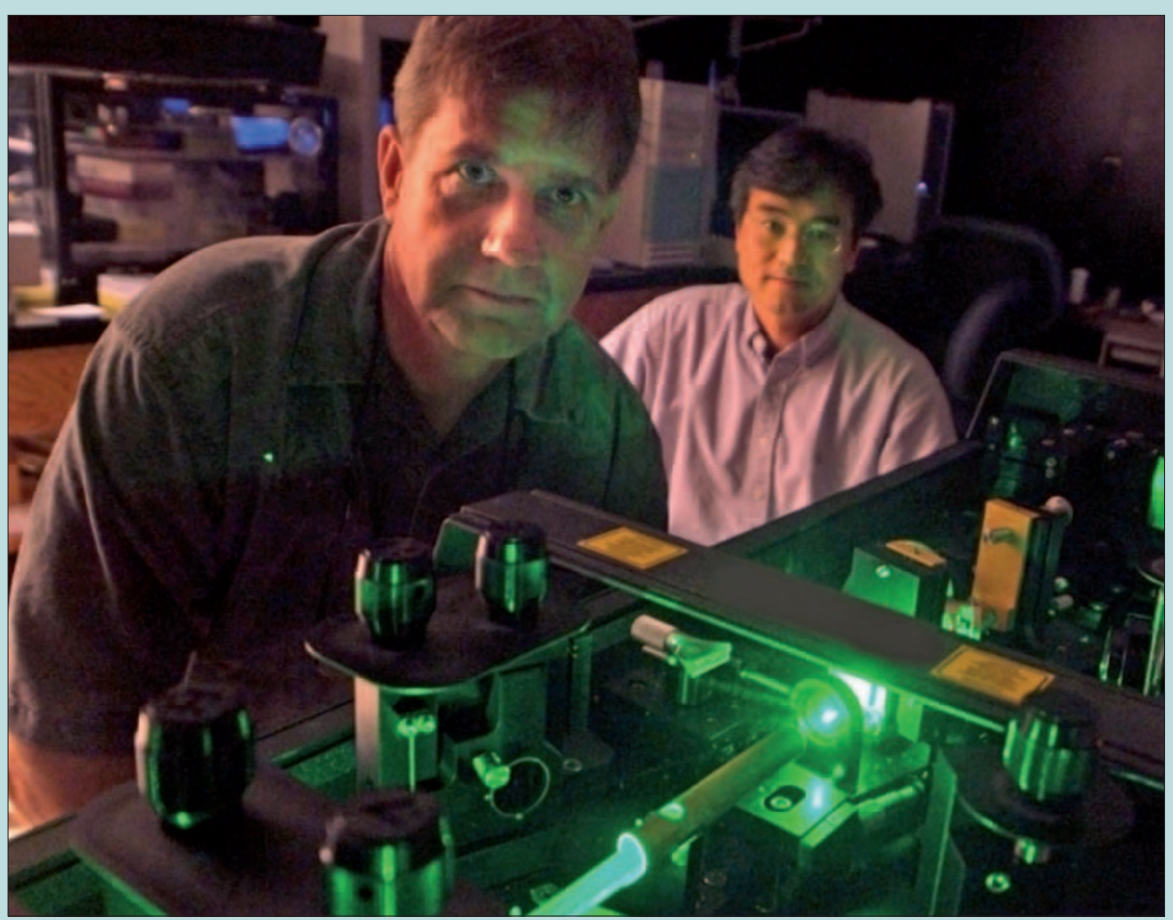

Drs Paul L. McNeil and Katsuya Miyake

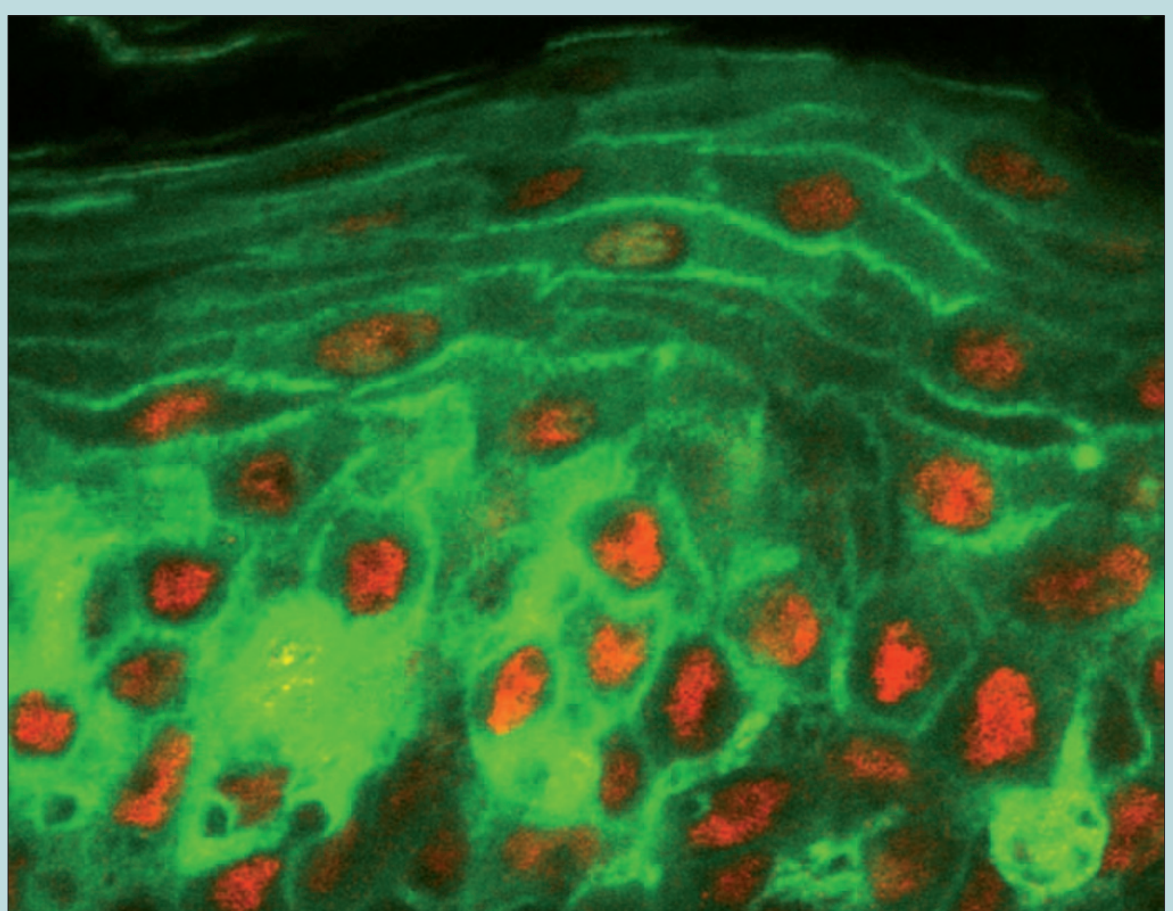

Epithelial cells (green) in the gum injured by brushing and resulting expression of c-fos (red) 


\section{DIARY}

September

FGDP (NW Region) Annual Study Day

Date: 19 September 2007

Venue: Alder Hey Educational Centre,

Liverpool

Email: louisecrees@mac.com

4th Annual Meeting of the European Society of Esthetic Dentistry

Date: 21-23 September 2007

Venue: Vienna, Austria

Email: iris.bobal@media.co.at

www.escdonline.eu

American Dental Association

Date: 27-30 September 2007

Venue: The Moscone Center,

San Francisco, USA

www.ada.org

\section{October}

British Society of Oral Implantology Date: 6 October 2007

Venue: The University of Glamorgan

Email:support@BSOl.org

www.BSOl.org

Oral Cancer: Challenges and Solutions

Date: 6 October 2007

Venue: UCL Eastman Dental Institute,

London

www.eastman.ucl.ac.uk

\section{BDTA Dental Showcase}

Date: 18-20 October 2007

Venue: NEC Birmingham

Tel: 01494789959

www.dentalshowcase.com

North of Scotland BDA Conference and Ceilidh

Date: 20 October 2007

Venue: Apex Hotel and Spa, Dundee

Email: bdascotland@hotmail.com

Tel: +44 (0)1382635964

Annual meeting of the Society of Craniofacial Genetics \& American Society of Human Genetics

Date: 23 October 2007

Venue: Convention Center, San Diego, California, USA

www.craniofacialgenetics.org

FDI Annual World Dental Congress

Date: 24-27 October 2007

Venue: Dubai, UAE

Email:congress@fdiworldental.org

www.fdiworldental.org

\section{Making complaining easier}

The Department of Health has launched a consultation paper on streamlining the complaints procedure in health and social care, including dentistry, which will make it easier for people to complain.

Currently there are separate complaints procedures for health and adult social care which make it difficult for people who use a combination of services to make a complaint or for those services to respond. There are also different arrangements for children's complaints.

The new unified health and social care arrangements aim to resolve complaints locally. There will be a more personal and flexible approach to handling complaints and a robust handling of all cases - not just those which are more complex. People will have the option of going direct to their primary care trust with a complaint about their $\mathrm{GP}$, instead of complaining directly to the GP and will have the option of going direct to their local authority with a complaint where the care has been arranged by the local authority.

Primary care trusts and local authority social services, which make

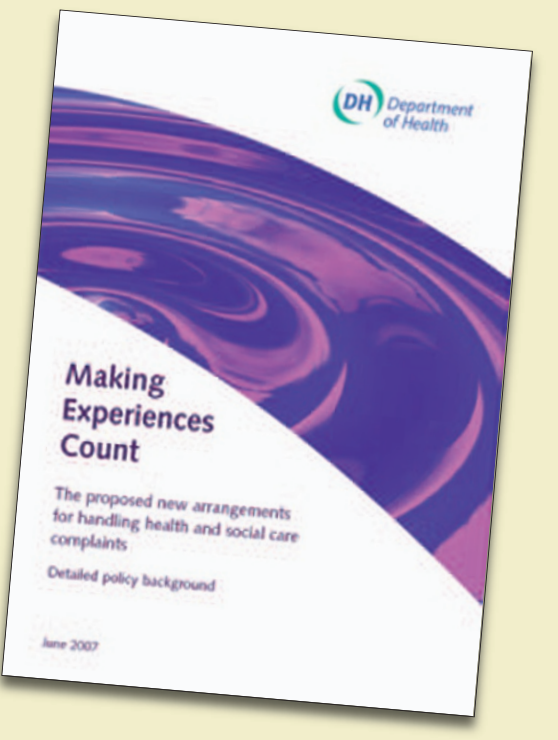

arrangements locally for services to be provided (service commissioners), will have a major role to ensure that services they commission have effective complaints processes in place and are delivered to a high standard.

The initial consultation will run for four months and close on 17 October 2007. Following that, the Department of Health will present a framework outlining the next steps. For further information visit www.dh.gov.uk.

\section{Inquiry into NHS contract}

The Commons Health Select Committee has announced that it will be undertaking an inquiry into the dental contracts, including the general dental contract and the NHS personal dental services agreement. Further details, including the terms of reference, will be announced on 11 October.

\section{Dedication to continuing education}

The US Academy Of General Dentistry (AGD) has announced the recipients for its 2007 Fellowship and Mastership Award, who received their honours at the AGD's Annual Meeting \& Exhibits in San Diego recently.

More than 500 dentists who received the award came from nearly every state in the United States, from Canada and other countries. These dentists are united by their dedication to remain current in their profession and to provide excellent patient care.

To earn the Fellowship Award, dentists must complete 500 hours of continuing dental education and pass a comprehensive written exam given by the AGD.
To date, more than 14,000 AGD members worldwide have earned Fellowship honours.

For the Mastership honours, dentists must complete more than 1,100 hours of quality continuing dental education in the 16 disciplines of dentistry, including 400 hours of handson courses. Currently more than 2,200 AGD members worldwide have earned Mastership honours.

'By completing the rigorous requirements for either a Fellowship or Mastership award, these dentists go above and beyond basic licensure requirements in their state to keep their practice on the cutting edge,' said AGD President Vincent Mayher. 


\section{Winning study}

Baber Khan has been awarded the Ruby Austin Shield for the Best VDP case presentation 2006. For his presentation, Indirect restoration of a last standing molar, he treated a patient as part of his vocational training year and presented his findings as a case report for colleagues and tutors. Each VDP was then questioned and marked on their case.

Baber Khan (left) receives the award from Dr Ruby Austin MBE

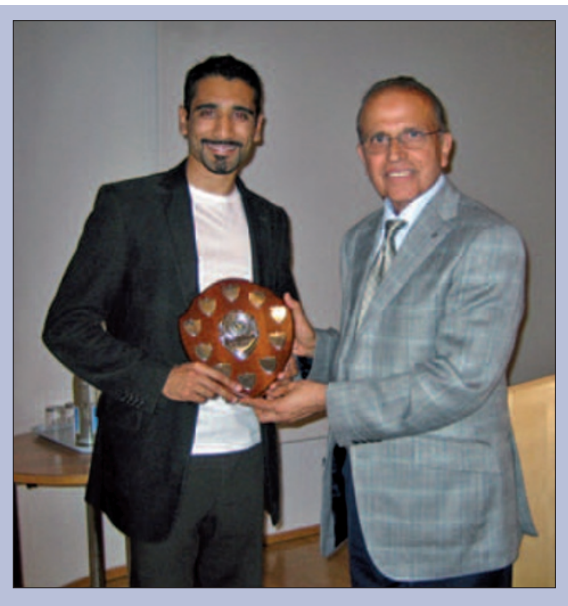

\section{Psychological factors affect mouth concludes review}

Stress may play a role in the development of periodontal diseases, according to a literature review in the Journal of Periodontology. It saw a strong relationship between stress and periodontal diseases with $57 \%$ of the studies included in the review showing a positive relationship between periodontal diseases and

psychological factors such as stress, distress, anxiety, depression, and loneliness.

Study author Daiane Peruzzo said more research was needed to determine the definitive relationship between stress and periodontal diseases, but that patients who minimised stress may be at less risk (J Periodontol 2007; 78:1491-1504).

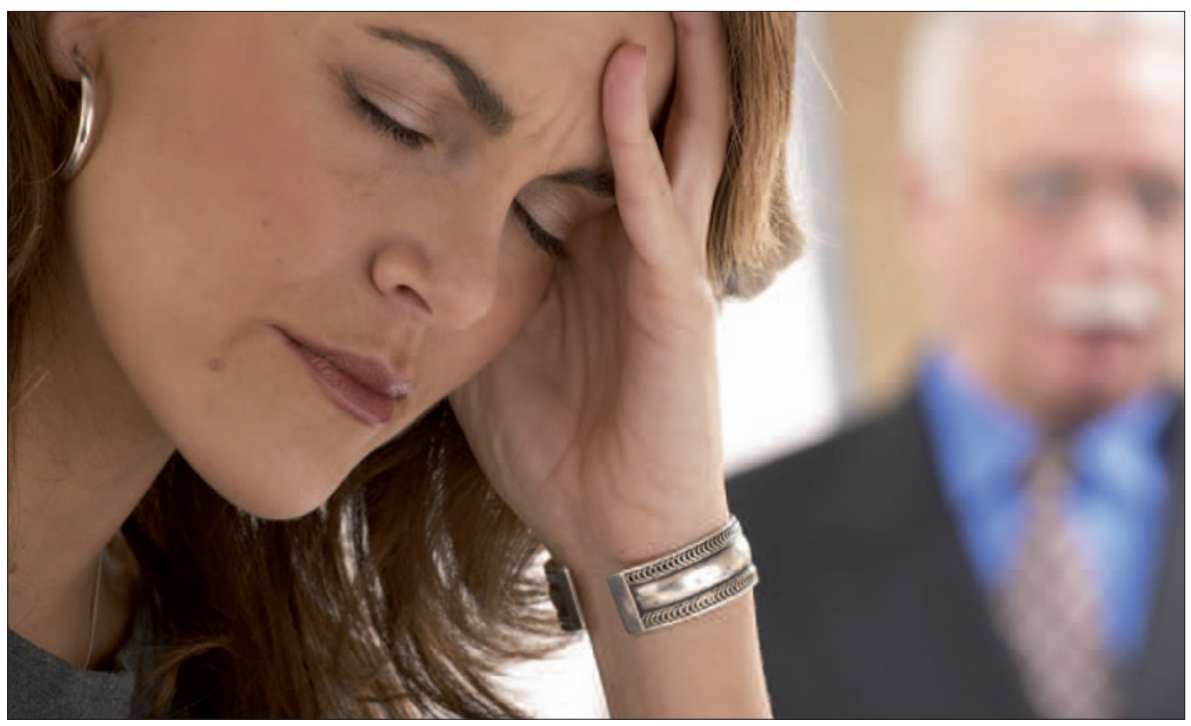

\section{Experiences of patients considered}

A protocol to meet the needs of patients who are referred to hospital with facial skeletal abnormalities should be considered in order to improve their care according to a study into the perspective of patients referred to hospital for orthognathic treatment.

The aim of the research was to find out whether patients make informed decisions about their treatment. The findings, published in the Journal of Orthodontics (2007; 34: 113-127), revealed that patients looked at treatment as a way of improving the function and bite of their teeth, looking more normal, which was a strong motivating factor and blending into the background as some patients were teased about their appearance. Studies to date have focused on the consequences of treatment itself rather than on the experiences of patients

\section{Effects of bone drugs on dental health}

The American Society for Bone and Mineral Research (ASBMR) has produced a report that examines the link between a class of widely prescribed drugs used to strengthen bones and osteonecrosis of the jaw (ONJ).

The report, authored by an international, multidisciplinary task force, was convened by the ASBMR to look at the possible association between ONJ, a deterioration of the jawbone, and a class of drugs known as bisphosphonates, which in recent years have been linked to the condition.

According to the American Dental Association, some 23 million Americans take oral bisphosphonates for osteoporosis. ONJ was first reported among cancer patients receiving high doses of bisphosphonate drugs as part of their treatment.

The disorder appears as an area of exposed bone in the lower and upper jaw often developing after tooth extraction, mouth injury and dental surgery. Some cases occurred as a result of no known injury.

According to Elizabeth Shane, cochair of the task force and immediate past President of the ASBMR, ONJ is rare in people taking low dose oral bisphosphonates for osteoporosis but she added that more research was needed to identify the risk factors and determine if changing the dosing schedules of bisphosphonates could reduce the incidence of $0 \mathrm{NJ}$.

'This new research agenda will help fill the considerable gaps in knowledge regarding this disorder and the recommendations will provide guidance for health care professionals in their care of patients currently on bisphosphonate therapy,' she explained.

The ASBMR task force formed in July 2006 is an international, multidisciplinary group of experts in the field including representatives from the United States National Institutes of Health and the Canadian Institutes of Health Research.

Both published and unpublished data on the occurrence of ONJ were examined, a case definition was determined and a future research agenda was recommended. 